\title{
Pseudo-precocious puberty in a 3-year old girl
}

\author{
Catherine Anne G Pangilinan-Vazquez*, Sioksoan C Cua, Lorna R Abad, Carmelita F Domingo, Sylvia C Estrada, \\ Caridad M Santos
}

From 7th APPES Biennial Scientific Meeting

Nusa Dua, Bali. 14-17 November 2012

Sertoli Cell Tumor is a rare sex cord tumor, comprising less than $5 \%$ of all sex cord tumors. It usually occurs in women of reproductive age but a few can also occur during early childhood. The usual manifestation among children is isosexual pseudoprecocity.

This is a case of a three-year-old girl who came in with a chief complaint of vaginal bleeding. She was born term to a G2P1 mother with no perinatal complications noted. At two years of age, she was noted to have gradual bilateral breast enlargement. There was no breast discharge noted. At two years and four months of age, she started to have vaginal bleeding which the mother claimed to occur on a "monthly" interval lasting for five to seven days. There was no history of trauma or any accompanying urinary symptoms. Initial consult was done in a local hospital where she was also noted to have enlarged head. Cranial CT Scan done was normal. Assessment made was precocious puberty. The patient was subsequently referred to our institution for further evaluation. On physical examination, pertinent findings include increased head circumference $(53.5 \mathrm{~cm}, \mathrm{z}$-score $>3$ S.D. $)$, weight $(16 \mathrm{~kg}, \mathrm{z}$-score $>0)$ and height $(100 \mathrm{~cm}, \mathrm{z}$-score $=0)$ within normal for age, Tanner Stage 3 for breast and Stage 1 for pubic hair. The rest of the physical exam findings were essentially normal. Bone age was appropriate for chronologic age. Hormonal work-up were as follows: FSH: 0.27 (NV:0.27-3.39 IU/L), LH: 0.22 (NV: 0.03-0.55 IU/L), Estradiol: 234 (NV:<10pg/mL), Prolactin: 783 (NV:80-500 microlU/mL), TSH: 9.4 (0.3-3.8 mIU/L), FT4: 22.4 (11-24 pmol/L). Pelvic ultrasound revealed upper borderline-sized uterus with slightly thickened round complex mass in the left adnexal region, to consider an ovarian neoplasm. Alpha-feto Protein, B-HCG, CA-125 tumor marker levels were all within normal limits. The patient subsequently underwent Exploratory

Section of Pediatric Endocrinology, University of the Philippines - Philippine General Hospital, Manila, Philippines
Laparotomy with Left Salphingo-oophorectomy. Intraoperatively, the left ovary was noted to be converted to a $5 \mathrm{~cm} \times 5 \mathrm{~cm} \times 3 \mathrm{~cm}$ solid mass with smooth surface and intact capsule. The right fallopian tube and ovary appeared normal. Histopathologic studies were consistent with Sertoli Cell Tumor of the left ovary, positive for Inhibin and Calretinin immunostaining. The vaginal bleeding and progressive breast enlargement ceased postoperatively. The estradiol and prolactin levels dropped (Estradiol: 234 to $37.3 \mathrm{pg} / \mathrm{mL}$ and Prolactin: 783 to 304 microIU $/ \mathrm{mL}$ ) one month after the surgery.

Published: 3 October 2013

doi:10.1186/1687-9856-2013-S1-P78

Cite this article as: Pangilinan-Vazquez et al.: Pseudo-precocious puberty in a 3-year old girl. International Journal of Pediatric Endocrinology 2013 2013(Suppl 1):P78. and take full advantage of:

- Convenient online submission

- Thorough peer review

- No space constraints or color figure charges

- Immediate publication on acceptance

- Inclusion in PubMed, CAS, Scopus and Google Scholar

- Research which is freely available for redistribution

Submit your next manuscript to BioMed Central www.biomedcentral.com/submit

,

